\title{
Etiology, incidence and mortality in patients with ventilator-associated pneumonia in adult general surgery and cardiac surgery intensive care units in University Hospital Dubrava
}

\author{
Etiologija, incidencija i smrtnost u bolesnika s pneumonijom povezanom s mehaničkom ventilacijom \\ u jedinicama intenzivnog liječenja opće i kardijalne kirurgije u Kliničkoj bolnici Dubrava

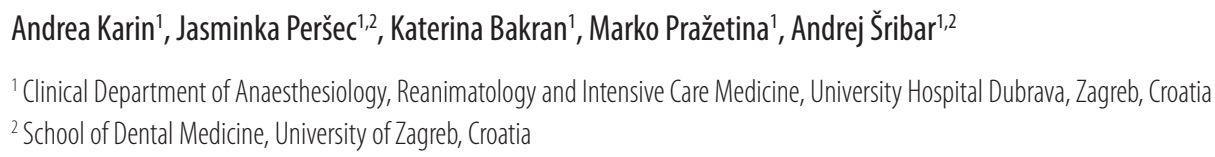

Keywords:

ventilator-associated pneumonia

hospital acquired pneumonia

mechanical ventilation

pneumonia

antimicrobial therapy

prevention

tracheotomy

Ključne riječi:

pneumonija povezana s mehaničkom ventilacijom pneumonija stečena u bolnici

mehanička ventilacija

pneumonija

antimikrobna terapija

prevencija

traheotomija

Primljeno: 02.11.2019.

Received: 02.11.2019.

Prihvaćeno: 18.01.2020.

Accepted: 18.01.2020.

$\triangle$ Corresponding author:

Asst. Prof. Jasminka Peršec, MD, PhD

Clinical Department of Anaesthesiology, Reanimatology and Intensive Care Medicine, University Hospital Dubrava, Gojko Šušak Avenue № 6, Zagreb 10000 , Croatia

School of Dental Medicine, University of Zagreb, Croatia, Gundulićeva 5, 10000 Croatia

e-mail: anestezija.predstojnica@kbd.hr

\begin{abstract}
Ventilator-associated pneumonia (VAP) and hospital acquired pneumonia (HAP) strongly contribute to morbidity and mortality in intensive care units. Hospital acquired pneumonia (HAP) is pneumonia occurring 48 hours upon admission and appears not to be incubating at the time of admission. Ventilator-associated pneumonia (VAP) is a type of HAP developing in intubated patients after more than 48 hours upon mechanical ventilation. HAP and VAP are common and serious complications present in hospitalized patients. Since the diagnosis of VAP and HAP are rarely documented, we wanted to assess the incidence of VAP in General Surgery and Cardiac Surgery Intensive Care Units in 2018 and analyse the patients and procedures related factors. Patients intubated and ventilated more than 96 hours during 2018 were included. Our findings have shown that incidence of VAP in two analysed ICUs in UH Dubrava is in line with VAP incidence found in literature due to successful preventive strategies and timely initiation of antimicrobial therapy and other adjunctive procedures.
\end{abstract}

\begin{abstract}
Sažetak
Pneumonija povezana s mehaničkom ventilacijom (engl. ventilator-associated pneumonia, VAP) i pneumonija stečena u bolnici (engl. hospital acquired pneumonia, HAP) snažno doprinose pobolu i smrtnosti u jedinicama za intenzivno liječenje. Bolnička pneumonija se javlja 48 sati nakon prijema u bolnicu i čini se da za vrijeme prijema nema inkubacije. Pneumonija povezana s mehaničkom ventilacijom (VAP) je vrsta bolničke pneumonije koja se razvija kod intubiranih bolesnika nakon više od 48 sati mehaničke ventilacije. HAP iVAP predstavljaju uobičajene i ozbiljne komplikacije kod hospitaliziranih bolesnika. Budući se VAP i HAP dijagnoze rijetko dokumentiraju, željeli smo procijeniti učestalost pneumonija povezanih s mehaničkom ventilacijom u jedinicama intenzivnog liječenja opće i kardijalne kirurgije u 2018. godini. U analizu su uključeni bolesnici koji su intubirani i ventilirani više od 96 sati tijekom 2018. godine. Rezultati istraživanja pokazuju da je učestalost VAP-a u dvije jedinice za intenzivno liječenje u Kliničkoj bolnici Dubrava u skladu s učestalošću VAP-a utvrđenom u literaturi zahvaljujući provođenju uspješnih preventivnih strategija i pravodobnog započinjanja antimikrobne terapije i drugih dodatnih procedura.
\end{abstract}

Introduction

Ventilator-associated pneumonia (VAP) and hospital acquired pneumonia (HAP) strongly contribute to morbidity and mortality in intensive care units. Hospital acquired pneumonia (HAP) is pneumonia occurring 48 hours upon admission and appears not to be incubating at the time of admission. Ventilator-associated pneumonia (VAP) is a type of HAP developing in intubated patients after more than 48 hours upon mechanical ventilation. ${ }^{[1]}$ HAP and VAP are common and serious complications present in hospitalized patients. Together, they are among the most common 
hospital-acquired infections (HAIs), accounting for $22 \%$ of all HAIs. ${ }^{[2]}$ HAP incidence ranges from 5 to more than 20 cases per 1000 hospital admissions. According to the literature, VAP incidence is expressed as number of cases per 1000 ventilator-days. US epidemiological studies report an incidence of VAP of 2-16 episodes per 1000 ventilator-days. ${ }^{[3,4]}$ The risk of VAP is estimated to be higher (2-3\%) during the 10 days of mechanical ventilation. ${ }^{[5]}$ However, the incidence of VAP seems to be decreasing, due to better preventive strategies. [6] The incidence is still very high in trauma and brain injury patients (50\%). ${ }^{[7]}$ Recently published data demonstrated that approximately $10 \%$ of the patients who required prolonged mechanical ventilation (greater than 21 days of mechanical ventilation for at least six hours per day ${ }^{[8]}$ were diagnosed with VAP. ${ }^{[9]}$ The mortality associated with VAP has been reported to range from $20 \%$ to $50 \%$, but the mortality directly related to VAP is debated; a recent meta-analysis derived from randomized VAP prevention studies estimated the attributable mortality at $13 \% \cdot{ }^{[10]} \mathrm{HAP}$ and VAP may be caused by different pathogens and can be polymicrobial. The common pathogens include gram-negative bacilli (Escherichia coli-5,9\%, Klebsiella pneumoniae-10,1\%, Enterobacter spp-8,16\%, Pseudomonas aeruginosa-16,6\%, Acinetobacter spp-6,6\%) and gram-positive cocci (Staphylococcus aureus-24,1\%, including MRSA, Streptococcus spp., as well as Enterococcus spp., common nosocomial bacteria, considered uncommon agent of airway illnesses that can be found among surgical and immunocompromised patients ${ }^{[11]}$. ${ }^{[12]}$ The 2016 Infectious Disease Society of America/ American Thoracic society guidelines for the management of HAP and VAP recommend a clinical diagnosis based upon a new lung infiltrate plus clinical evidence that the infiltrate is of infectious origin, which includes the new onset of fever, purulent sputum, leucocytosis, worsening of oxygenation parameters, and significantly positive microbiologic tracheal or bronchoalveolar lavage with $10^{5}$ or $10^{4} \mathrm{CFU} / \mathrm{ml}^{[1]}$ There are some predisposing factors specific to $\mathrm{VAP}^{[13]}$, mainly endotracheal intubation and mechanical ventilation ${ }^{[14,15]}$. Risk factors predisposing to VAP are determined in part by the duration of exposure to the ICU environment and the presence of host factors and treatment related factors that predispose to the development of $\mathrm{VAP}^{[16]}$, by increasing the likelihood for colonization of the aerodigestive tract with pathogenic bacteria (e.g., prior antibiotic exposure, age $>60$ years, chronic obstructive pulmonary disease) and predisposing to the aspiration of contaminated secretions (e.g., supine positioning, coma, head trauma, etc. $)^{[16,17]}$.

\section{Material and Methods}

This research was conducted as a retrospective observational study, using data obtained from medical records. It includes data from patients treated in General Surgery and Cardiac Surgery Intensive Care Units in the University Hospital Dubrava in 2018. The patients who were intubated and ventilated more than 96 hours from BIS computer database ${ }^{[18]}$ were screened, and the patients with positive bacterial growth in tracheal aspirate or bronchoalveolar lavage specimens were selected for further analysis (Figure 1).

Traditional clinical criteria for pneumonia (fever or hypothermia, leucocytosis or leukopenia, increase in volume of respiratory secretions or a change in character of the secretions, a new or progressive infiltrate on the chest X-ray) $)^{[19]}$ and significantly positive microbiologic growth of tracheal aspirate or bronchoalveolar lavage specimens with $10^{5}$ or $10^{4} \mathrm{CFU} / \mathrm{ml}$ to single out patients with VAP. The time of presentation, combined with mechanical ventilation duration, was the key factor to distinguish between patients diagnosed with VAP or HAP. Patient age, sex, ASA (American Society of Anaesthesiologists) classification (grading system for preoperative health of the surgical patients based on 6 classes: ASA I stands for a normal healthy patient and ASA VI is a declared brain-dead patient whose organs are being removed for donor purposes) - figure 2, duration of mechanical ventilation, emergency and brain injury patients, adjunctive pulmonary procedures (bronchoscopy, pleural puncture, chest drainage), microbiological findings, revision of antibiotic therapy (change or de-escalation), elapsed time from diagnosis to tracheotomy, mortality, CPIS (Clinical Pulmonary Infection Score) and SOFA (Sequential Organ Failure Assessment) score were evaluated.

\section{Results}

In analysed ICUs, 92 patients were ventilated for more than 96 hours during 2018. 14 patients (15\%) had positive criteria for VAP and 19 (20\%) of them were diagnosed with HAP. Among 14 patients diagnosed with VAP, mean time from the admission to the ICU to diagnosis was $7.9 \pm 2.3$ days. Mean patient age was $64 \pm 15$ years, and most of them were males (79\%). $71 \%$ of patients were admitted as emergencies and $43 \%$ of them had severe neurotrauma. According to the ASA classification (American Society of Anaesthesiologists) of perioperative risk of complication during surgery and anaesthesia due to patients ' existing comorbidities, more than half of the patients (57\%) were initially evaluated as ASA IV (a patient with severe systemic 
FIGURE 1 FLOWCHART DEPICTING SELECTION CRITERIA FOR VAP AND HAP AMONG PATIENTS THAT WERE VENTILATED AND INTUBATED OVER $96 \mathrm{H}$

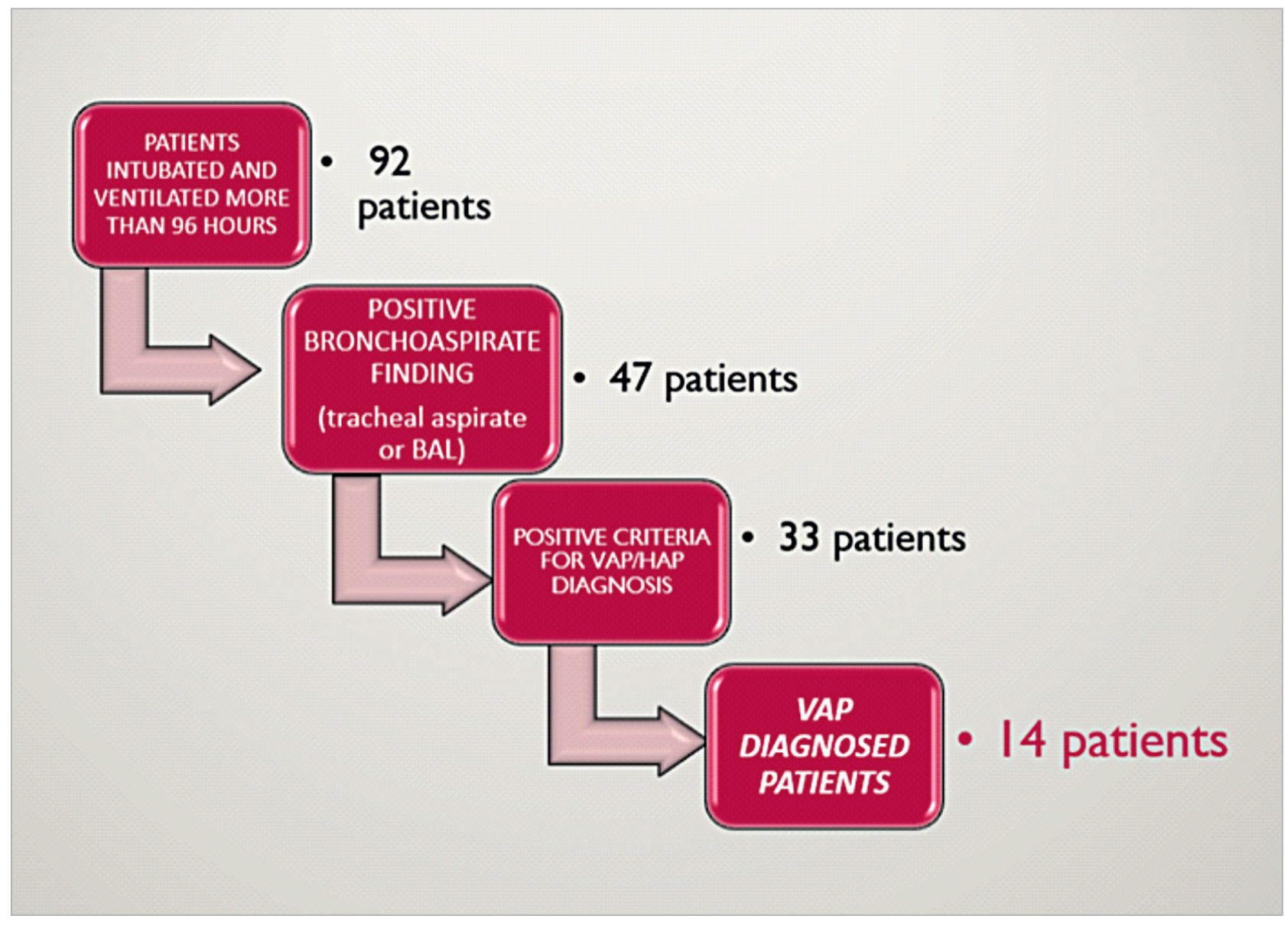

disease that is a constant threat to life). (Figure 1) Median duration of mechanical ventilation was 11 days (from 3 to 82 days). Two patients required prolonged mechanical ventilation. Tracheotomy was performed in 12 patients with VAP (85\%) and the mean time from intubation to tracheostomy was $7.7 \pm 3.1$ days. Etiological agents of the VAP in our ICU are presented in Table 1. Gram negative pathogens were found in 11 cases $(79 \%)$ while gram positive pathogens were found 3 in cases $(21 \%)$. There was no significant difference in the 28-day survival depending on pathogen agent. An antibiotic therapy modification was required in 5 cases (36\%). Certain pulmonary invasive procedures indicated for diagnostic (BAL) and therapeutic (airway lavage and aspiration, pleural effusion) reasons in patients diagnosed with VAP are shown in the Table 2. At the time of setting the diagnosis, the median CPIS was 5, and the mean SOFA score was 10.1. The mortality rate among the patients was $64 \%$ (median day of death was $14.9 \pm 11.3$ ). There was no statistically significant difference in mortality between VAPs and HAPs and emergency admission did not affect mortality.
TABle 1. Frequencies of PATHogens

\begin{tabular}{|l|l|l|}
\hline & Counts & $\%$ of Total \\
\hline Acinetobacter baumannii & 4 & $29 \%$ \\
\hline Pseudomonas aeruginosa & 3 & $21 \%$ \\
\hline Enterococcus faecalis & 2 & $14 \%$ \\
\hline Enterobacter cloacae & 2 & $14 \%$ \\
\hline Klebsiella oxytoca & 1 & $7 \%$ \\
\hline Staphylococcus aureus & 1 & $7 \%$ \\
\hline Klebsiella pneumoniae & 1 & $7 \%$ \\
\hline
\end{tabular}

TABle 2. Number of PUlMONARY INVASIVE PROCEDURES

\begin{tabular}{|l|l|l|}
\hline & YES & NO \\
\hline bronchoscopy & $6(43 \%)$ & $8(57 \%)$ \\
\hline pleurocentesis & $2(14 \%)$ & $12(86 \%)$ \\
\hline chest drainage & $5(36 \%)$ & $9(64 \%)$ \\
\hline
\end{tabular}


Figure 2. ASA Classification of VAP PATIENTS

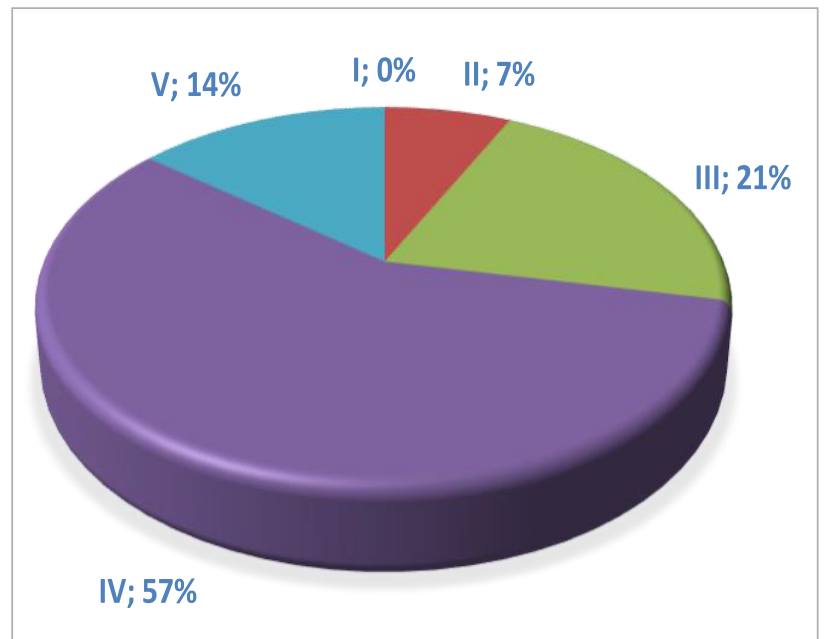

\section{Discussion and Conclusion}

The aim of this study was to assess the incidence of VAP and HAP in the University Hospital Dubrava General Surgery and Cardiac Surgery Intensive Care Units in 2018, but our subject of interest was primarily VAP. Therefore, we analysed the data from VAP patients. Due to the limitations in BIS software package, only patients ventilated more than 96 hours were included, and the incidence was not expressed as number of cases per 1000 ventilator-days.

Nevertheless, upon literature search and comparison with published data, similar rate of VAP incidence was found in our centre (10-27\% according to published data) ${ }^{[20,21]}$. Several studies in the USA and UK found that the most common pathogens causing VAP are Staphylococcus aureus $(24,1 \%)$ and Pseudomonas aeruginosa $(16,6 \%)^{[12]}$, which is different from findings in our centre, in which Acinetobacter baumannii was the most common pathogen (4 cases). In published studies, the crude mortality of patients with VAP is highly variable (10-70\%) according to case mix $^{[22-24]}$. Among the patients in our centre mortality rate was $64 \%$.

It is worth noting that only surgical patients were analysed, and most of them were categorized as high risk according to the ASA classification (III and IV). Also, the reason for extended ventilation was not only respiratory failure, but also surgical complications and neurological status due to neurotrauma. Among 14 VAP diagnosed patients, only two required prolonged mechanical ventilation. We have established that preventive strategies in our ICU are well executed and successful, including supine patient positioning, preventing aspiration (endotracheal tube airway cuff pressure maintained at 20-30 $\mathrm{cmH}_{2} \mathrm{O}$ ), subglottic drainage, oral hygiene with hexetidine, and early initiation of empirical therapy with broad-spectrum agents to which most of infective agents found in patients treated in $\mathrm{UH}$ Dubrava are susceptible, and in the majority of cases the modification was not required. Furthermore, early respiratory rehabilitation performed by physiotherapists together with spontaneous breathing trials was performed with goal of weaning ventilated patients as soon as possible. The question of early (performed 2-14 days - mean 7 days) versus late (performed 10 days to three weeks - mean 14 days) tracheostomy remains unresolved in the medical literature. ${ }^{[25]}$ Nevertheless, some evidence suggests that early tracheostomy may improve some short-term clinical outcomes. [26] When compared with late tracheostomy, early tracheostomy was associated with a higher likelihood of weaning from the ventilator, a higher likelihood of being discharged from the ICU within 28 days, a trend towards a lower rate of pneumonia and similar survival at one month. ${ }^{[26]}$ In our centre, we prefer early tracheostomy (mean $7.7 \pm 3.1$ day) and this also can be a part of preventive strategies. In conclusion, data gathered in this preliminary observational monocentric study show that rates of VAP occurrence observed in surgical ICUs in UH Dubrava are in accordance to data reported from other centres. Prospective observational studies are to be performed to further assess risk factors and outcomes in VAP patients.

\section{REFERENCES}

${ }^{[1]}$ Kalil AC, Metersky ML, Klompas M, et al. Management of Adults With Hospital-acquired and Ventilator-associated Pneumonia: 2016 Clinical Practice Guidelines by the Infectious Diseases Society of America and the American Thoracic Society. Clin Infect Dis 2016;63:e61.

${ }^{[2]}$ Magill SS, Edwards JR, Fridkin SK; Emerging Infections Program Healthcare-Associated Infections Antimicrobial Use Prevalence Survey Team. Survey of healthcare-associated infections. N Engl J Med 2014; 370:2542-3.

${ }^{[3]}$ Rosenthal VD, Bijie H, Maki DG, et al. International Nosocomial Infection Control Consortium (INICC) report, data summary of 36 countries, for 2004-2009. Am J Infect Control 2012; 40: 396-407.

${ }^{[4]}$ Rosenthal VD, Maki DG, Jamulitrat S, et al. International Nosocomial Infection Control Consortium (INICC) report, data summary for 2003-2008, issued June 2009. Am J Infect Control 2010; 38: 95-104.

${ }^{[5]}$ Cook DJ, Walter SD, Cook RJ, et al. Incidence of and risk factors for ventilator-associated pneumonia in critically ill patients. Ann Intern Med 1998; 129: 433-440.

${ }^{[6]}$ Rello J, Ollendorf DA, Oster G, et al. Epidemiology and outcomes of ventilator-associated pneumonia in a large US database. Chest 2002; 122: 2115-2121. 
${ }^{[7]}$ Asehnoune K, Seguin P, Allary J, et al. Hydrocortisone and fludrocortisone for prevention of hospital-acquired pneumonia in patients with severe brain injury (Corti-TC): a double blind multicenter phase 3, randomised placebo-controlled trial. Lancet Respir Med 2014; 2: 706-716.

${ }^{[8]}$ MacIntyre NR, Epstein SK, Carson S, et al. Management of patients requiring prolonged mechanical ventilation: report of a NAMDRC consensus conference. Chest 2005; 128:3937.

${ }^{[9]}$ Wang Y, Eldridge N, Metersky ML, et al. National trends in patient safety for four common conditions, 2005-2011. N Engl J Med 2014; 370:341-51.

${ }^{[10]}$ Melsen WG, Rovers MM, Groenwold RH, et al. Attributable mortality of ventilator-associated pneumonia: a meta-analysis of individual patient data from randomised prevention studies. Lancet Infect Dis 2013; 13:665-71.

${ }^{[11]}$ Savini V, Gherardi G, Astolfi D, et al. Insights into Airway Infections by Enterococci: A Review. Recent Pat Antiinfect Drug Discov 2012;7:36-44.

${ }^{[12]}$ Jones RN. Microbial etiologies of hospital-acquired bacterial pneumonia and ventilator-associated bacterial pneumonia. Clin Infect Dis 2010;51:S81-S87.

${ }^{[13]}$ Vincent JL. Nosocomial infections in adult intensive-care units. The Lancet 2003;14:2068-77.

${ }^{[14]}$ Appelgren P, Hellstrom I, Weitzberg E, et al. Risk factors for nosocomial intensive care infection: a long-term prospective analysis. Acta Anaesthesiol Scand 2001;45:710-9.

${ }^{[15]}$ Tejada AA, Bello DS, Chacon VE, et al. Risk factors for nosocomial pneumonia in critically ill trauma patients. Crit Care Med 2001;29:304-9.
${ }^{[16]}$ Kollef MH. Prevention of hospital-associated pneumonia and ventilator-associated pneumonia. Crit Care Med 2004;32: 1396-405.

${ }^{[17]}$ Cook D.J., Kollef M.H. Risk factors for ICU-acquired pneumonia. JAMA 1998;279:1605-6.

${ }^{[18]}$ IN-CON d.o.o.. Bolnički info sustav., Available at http://www. in-con.hr/bolnicki.aspx

${ }^{[19]}$ Kollef $\mathrm{MH}$. Ventilator- associated complications, including infection- related complications: The way forward. Crit Care Clin 2013; 29:33-50.

${ }^{[20]}$ Kalanuria AA, Zai W, Mirski M. Ventilator-associated pneumonia in the ICU. Critical Care 2014;18:208.

${ }^{[21]}$ Metersky ML, Wang Y, Klompas M, Eckenrode S, Bakullari A, Eldridge N. Trend in Ventilator-Associated Pneumonia Rates Between 2005 and 2013. JAMA 2016;316:2427-2429.

${ }^{[22]}$ Klompas M. Does this patient have ventilator-associated pneumonia? JAMA 2007;297:1583-93.

${ }^{[23]}$ Safdar N, Dezfulian C, Collard HR, et al. Clinical and economic consequences of ventilator-associated pneumonia: a systematic review. Crit Care Med 2005;33:2184-93.

${ }^{[24]}$ Timsit J, Zahar J, Chevret S. Attributable mortality of ventilator-associated pneumonia. Curr Opin Crit Care 2011;17:464-71.

${ }^{[25]}$ Andriolo BN, Andriolo RB, Saconato H, Atallah ÁN, Valente O. Early versus late tracheostomy for critically ill patients. Cochrane Database Syst Rev. 2015;1(1):CD007271.

[26] Terragni PP, Antonelli M, Fumagalli R, et al. Early vs late tracheotomy for prevention of pneumonia in mechanically ventilated adult ICU patients: a randomized controlled trial. JAMA 2010;303:1483. 